\title{
Rhizosphere Dynamics as Influenced by Nitrogen Levels and Plant Geometry in Groundnut (Arachis hypogeae L.)
}

\author{
Mandakranta Chakraborty ${ }^{*}$ and M. Martin Luther \\ Department of Agronomy, Agricultural College, Bapatla-522101, India \\ *Corresponding author
}

Keywords

Nitrogen Levels, Population Densities, Nutrient Content, Fungi, Bacteria, Actinomycetes

\section{Article Info}

Accepted:

20 February 2020 Available Online: 10 March 2020

\section{A B S T R A C T}

A field experiment was conducted at Agricultural College Farm, Bapatla, Andhra Pradesh on sandy upland soils during post-monsoon, 2018. The experiment consisted of four levels of nitrogen and four population densities laid out in randomized block design with factorial concept. Nutrient content significantly increased with increase in nitrogen levels and higher content of $\mathrm{N}, \mathrm{P}, \mathrm{K}, \mathrm{Zn}$ and Fe were obtained with $90 \mathrm{~kg} \mathrm{~N} \mathrm{Na}^{-1}$ which was significantly on par with $60 \mathrm{~kg} \mathrm{~N} \mathrm{ha}^{-1}$. Nutrient content was higher with wider spacing of $30 \times 10 \mathrm{~cm}$, which was on par with $25 \times 10$ $\mathrm{cm}$. The microbial population was significantly influenced by levels of nitrogen fertilization and significantly superior population of fungi, bacteria and actinomycetes was found with $90 \mathrm{~kg} \mathrm{~N} \mathrm{ha}^{-1}$. Microbial responded significantly to population densities and significantly higher microbial count was obtained with 15 x $10 \mathrm{~cm}$ spacing.

\section{Introduction}

Groundnut (Arachis hypogeae L.) is a unique legume cum oilseed crop grown particularly in southern and western parts of India. Groundnut is an important source of edible oil in India and world. Its importance lies in high oil $(45 \%)$ and protein $(26 \%)$ content and minerals like iron, calcium and phosphorus. Rhizosphere is the region of soil in the vicinity of plant roots in which the chemistry and microbiology is influenced by their growth, respiration and nutrient exchange.
Rhizosphere processes such as root-induced changes in $\mathrm{pH}$ and root exudates release play a key role in nutrient acquisition. Rhizosphere chemistry can be significantly changed according to the form of $\mathrm{N}$ taken up: ammonium supply may reduce rhizosphere $\mathrm{pH}$ through promoting proton release and activation of wall-loosening processes, leading to root cell elongation and thus improving the nutrient content. Moreover, ammonium localization together with $\mathrm{P}$ caused rhizosphere acidification and increased $\mathrm{P}$ availability. 
Moreover, bacteria like Bacillus cereus, $B$. subtilis, Pseudomonas fluorescens occurs qualitatively in the rhizosphere soil than nonrhizosphere soil due to exudates secreted by the plant which could have made rhizosphere samples richer in nutrients there by increasing the diversity of microbes isolated.

In the light of the above knowledge, the experiment was conducted to evaluate rhizosphere dynamics and crop geometry in groundnut.

\section{Materials and Methods}

A field experiment was conducted at Agricultural College Farm, Bapatla, Andhra Pradesh on sandy upland soils during postmonsoon, 2018 on rhizosphere dynamics and crop geometry in groundnut (Arachis hypogeae L.). The experiment was laid out in a randomized block design with factorial concept and replicated thrice, consisting sixteen treatments with four levels of nitrogen (ammonium sulphate as source) viz., $0 \mathrm{~kg}$ ha ${ }^{1}, 30 \mathrm{~kg} \mathrm{ha}^{-1}, 60 \mathrm{~kg} \mathrm{ha}^{-1}$ and $90 \mathrm{~kg} \mathrm{ha}^{-1}$ with 60 $\mathrm{kg} \mathrm{ha}^{-1}$ and $90 \mathrm{~kg} \mathrm{ha}^{-1}$ given in three splits i.e., $1 / 3^{\text {rd }}$ basal, 1/3 ${ }^{\text {rd }} @ 30$ DAS and 1/3 ${ }^{\text {rd }} @ 60$ DAS and four levels of population densities viz., $30 \times 10 \mathrm{~cm}, 25 \times 10 \mathrm{~cm}, 20 \times 10 \mathrm{~cm}$ and $15 \times 10 \mathrm{~cm}$. Phosphorous and potassium was applied at the rate of $40 \mathrm{~kg} \mathrm{ha}^{-1}$ and $50 \mathrm{~kg} \mathrm{ha}^{-1}$ respectively as basal dose to all the treatments uniformly. Gypsum was applied at early flowering stage@ $500 \mathrm{~kg} \mathrm{ha}^{-1}$. The soil was sandy in texture with $85.6 \%$ sand, $5.7 \%$ silt and $8.7 \%$ clay, near neutral in reaction $(\mathrm{pH}$ 6.83), low in EC $\left(0.06 \mathrm{dS} \mathrm{m}^{-1}\right)$, low in organic carbon $(0.15 \%)$, low in available nitrogen (120 kg ha $\mathrm{kg}^{-1}$ and medium in available phosphorus (29.2 $\mathrm{kg} \mathrm{ha}^{-1}$ ) and potassium (168 $\left.\mathrm{kg} \mathrm{ha}^{-1}\right)$.The rainfall during the crop growth period was $191.2 \mathrm{~mm}$.

The enumeration of total bacteria, fungi and actinomycetes from the soil samples was estimated by following the standard dilution pour plate count technique. Nutrient agar (NA) for bacteria, Potato dextrose agar (PDA) for fungi and Ken- Knight and Munaier's medium for actinomycetes were used for enumeration. N, P, K, Zn and Fe in haulm and seed were determined according to the standard method described by Jackson. (1973). The observations on nutrient content, and microbial count were recorded and subjected to statistical analysis.

\section{Results and Discussion}

\section{Nutrient Contents}

\section{Nitrogen Content (\%)}

Nitrogen content was estimated on seed and haulm. The content data presented in table 1 , indicated significant differences due to levels of nitrogen and population densities. The interaction was however found to be nonsignificant.

Among the levels of nitrogen, nitrogen content was significantly higher with $90 \mathrm{~kg} \mathrm{~N}$ $\mathrm{ha}^{-1}$ and on par with $60 \mathrm{~kg} \mathrm{~N} \mathrm{ha}^{-1}$ as compared to 30 and $0 \mathrm{~kg} \mathrm{~N} \mathrm{ha}^{-1}$. Among the population densities significantly higher content of nitrogen was observed with wider spacing of $30 \times 10 \mathrm{~cm}$ and it was on par with $25 \times 10 \mathrm{~cm}$. Moreover, the data reveals that the content of nitrogen was more in seeds than that of haulms. Steady supply of nutrients throughout the crop growth period might have resulted in increasing the nutrient availability for uptake and better utilization by the crop which in turn produced more photosynthates and better partitioning of dry matter from source to sink. Localised placement of $\mathrm{P}$ and ammonium fertilizer might have modified the rhizosphere processes by stimulating root proliferation and by ammonium induced rhizosphere acidification, thereby increasing $\mathrm{N}$ acquisition by plants as reported by Jing et al., 2010. 
These results are in conformity with the findings of Chavan et al., 2014, El- Habbasha et al., 2013 and Elayaraja et al., 2009.

\section{Phosphorus content (\%)}

Levels of nitrogen had significant effect in phosphorus content of groundnut crop. Phosphorus content was noticed to be significantly higher with $90 \mathrm{~kg} \mathrm{~N}^{-1}$ when compared to 30 and $0 \mathrm{~kg} \mathrm{~N} \mathrm{ha}^{-1}$ and was on par with $60 \mathrm{~kg} \mathrm{~N}^{-1}$. Population densities responded significantly to phosphorus content in groundnut. Results revealed that significantly higher content of $\mathrm{P}$ was observed with $30 \times 10 \mathrm{~cm}$, however, it was on par with $25 \times 10 \mathrm{~cm}$. The interaction between nitrogen levels and population densities was not significant. Further, the data reveals that the content of phosphorus was more in seeds than that of haulms. Improved root growth and its functional activity helped in greater extraction of nutrients due to acidification of rhizosphere which might have increased the availability of phosphorus and N-driven mining of nutrients. These results are in conformity with the findings of Chavan et al., 2014, El- Habbasha et al., 2013 and Jing et al., 2010.

\section{Potassium content (\%)}

The data on potassium content due to levels of nitrogen and population densities is presented in table 1. Results indicated that levels of nitrogen and population densities had significant effect in potassium content of groundnut crop. Application of $90 \mathrm{~kg} \mathrm{~N} \mathrm{ha}^{-1}$ resulted in significantly higher $\mathrm{K}$ content which was on par with $60 \mathrm{~kg} \mathrm{~N}^{-1}$ and $30 \mathrm{~kg}$ $\mathrm{N}$ ha ${ }^{-1}$. Population densities did not respond significantly to potassium content. The interaction between nitrogen levels and population densities did not differ significantly. Higher nutrient concentrations in plants might be because of increased nutrient availability due to modification of rhizosphere. Further, improved root growth and its functional activity also helped in greater extraction of potassium. These results are in conformity with the findings of Chavan et al., 2014 and El- Habbasha et al., 2013.

\section{Zinc content $\left(\mathrm{mg} \mathrm{kg}^{-1}\right)$}

The results pertaining to zinc content indicated that levels of nitrogen and population densities had significant effect on the crop. Zinc content increased with increase in levels of nitrogen. Application of $90 \mathrm{~kg} \mathrm{~N}$ $\mathrm{ha}^{-1}$ resulted in significantly higher content of $\mathrm{Zn}$ over 30 and $0 \mathrm{~kg} \mathrm{~N} \mathrm{ha}^{-1}$, however it was on par with $60 \mathrm{~kg} \mathrm{~N} \mathrm{ha}{ }^{-1}$. Zinc content responded significantly to population densities. Wider spacing of $30 \times 10 \mathrm{~cm}$ resulted in significantly higher zinc content which was on par with $25 \mathrm{x} 10 \mathrm{~cm}$. Ammonium-induced rhizosphere acidification in the localized fertilizer zone significantly enhanced $\mathrm{Zn}$ availability and acquisition, resulting in improved growth and $\mathrm{Zn}$ uptake. These results are in conformity with the findings of Ma et al., 2013 and Qinghua et al., 2014.

\section{Iron content $\left(\mathrm{mg} \mathrm{kg}^{-1}\right)$}

The data pertaining to iron content due to levels of nitrogen and population densities are presented in table 2. Iron content was significantly influenced with levels of nitrogen. Nitrogen application with $90 \mathrm{~kg} \mathrm{~N}$ $\mathrm{ha}^{-1}$ resulted in more content of iron over 30 and $0 \mathrm{~kg} \mathrm{~N} \mathrm{ha}^{-1}$; however it was on par with $60 \mathrm{~kg} \mathrm{~N} \mathrm{ha}{ }^{-1}$. Population densities and their interaction, however, did not influence iron content. Increased iron availability might have increased nodulating bacteria as iron is a constituent of ferridoxin and leghaemoglobin which might have increased the yield of groundnut with higher uptake of iron. Nongraminaceous plants increase iron availability by releasing protons that lower the soil $\mathrm{pH}$ 
and organic acid anions. Ammonium-induced rhizosphere acidification in the localized fertilizer zone significantly enhanced $\mathrm{Fe}$ availability and acquisition, resulting in improved growth and $\mathrm{Fe}$ nutrition. These results are in conformity with the findings of Ma et al., 2013 and Qinghua et al., 2014.

\section{Assessment of CFU of total fungi, bacteria and actinomycetes}

\section{Total fungal count $\left(\mathrm{CFU} \mathrm{g^{-1 }}\right)$}

The results pertaining to total fungal count presented in table 3 indicated significant difference in fungal population with various nitrogen levels and population densities. The interaction between levels of nitrogen and population densities however failed to produce any significant result. Application of $90 \mathrm{~kg} \mathrm{~N} \mathrm{ha}{ }^{-1}$ recorded significantly highest number of fungal count compared to 30 and 0 $\mathrm{kg} \mathrm{N} \mathrm{ha}^{-1}$; however it was on par with $60 \mathrm{~kg} \mathrm{~N}$ $\mathrm{ha}^{-1}$.

It might have resulted due to presence of organic substance from the root exudates and dead root cells and decrease in rhizosphere $\mathrm{pH}$ which favoured the growth of fungi. This is in line to the results reported by Aliyu and Oyeyiola, 2012 and Oyewole et al., 2012. Higher population density with 15 x $10 \mathrm{~cm}$ resulted in more population of fungi, however, it was found to be on par with $20 \mathrm{x}$ $10 \mathrm{~cm}$ spacing.

Lowest population was observed with lower population density of $30 \mathrm{x} 10 \mathrm{~cm}$. Root exudation is positively correlated with root growth; it means that actively growing root systems secrete more exudates. Root exudates mediate positive interactions which include symbiotic associations with beneficial microbes, such as mycorrhizae, rhizobia and plant growth-promoting rhizobacteria (PGPR), thereby increasing fungal count. This is in agreement with Badri and Vivanco, 2009 and Garcia et al., 2001.

\section{Total bacterial count $\left(\mathrm{CFU} \mathrm{\textrm {g } ^ { - 1 }}\right)$}

The data on total bacterial count indicated (Table 3) significant difference in bacterial population with various nitrogen levels and population densities, however, their interaction failed to produce significant result. Significantly superior number of bacterial cfu $\mathrm{g}^{-1}$ was observed at $90 \mathrm{~kg} \mathrm{~N} \mathrm{ha}^{-1}$ as compared to other levels of nitrogen. This might be a result of the additional nitrogen provided by the additives which the bacteria breakdown for plant use resulting to the release of more exudates and plant products for the diazotrophs, hence, increasing in rhizosphere bacterial biomass as reported by Das and Dkhar, 2011. Population densities responded significantly to bacterial population. Narrower spacing with $15 \times 10 \mathrm{~cm}$ resulted in higher population of bacteria, however it was found to be on par with $20 \times 10 \mathrm{~cm}$ spacing. The plant root-soil interface is an environment with high microbial inoculum, composed of both pathogenic and beneficial microbes. If a microscopic organism is sensed by the roots possibly because of specific receptors, then the presence of a macroscopic neighboring root might be better perceived by the plant. Interaction of roots of a plant with its neighboring plant might have increased bacterial population with closer density. This result is in agreement with Badri and Vivanco, 2009 and De-la-Pena et al., 2008.

\section{Total actinomycetes count (CFU g $\left.{ }^{-1}\right)$}

The perusal of data presented in table 3, pertaining to total actinomycetes count indicated significant difference in actinomycetes population with various nitrogen levels and population densities, their interaction however failed to produce significant result. 
Table.1 N, P, K content (\%) of groundnut as influenced by nitrogen levels and population densities

\begin{tabular}{|c|c|c|c|c|c|c|}
\hline \multirow[t]{3}{*}{ Treatments } & \multicolumn{6}{|c|}{ Content (\%) } \\
\hline & \multicolumn{2}{|c|}{$\mathbf{N}$} & \multicolumn{2}{|c|}{$\mathbf{P}$} & \multicolumn{2}{|c|}{$\mathbf{K}$} \\
\hline & Haulm & Seed & Haulm & Seed & Haulm & Seed \\
\hline \multicolumn{7}{|c|}{ Nitrogen levels $(\mathbf{N})$} \\
\hline N1: 0 kg N ha-1 & 1.74 & 3.08 & 0.12 & 0.26 & 1.19 & 0.70 \\
\hline N2: $30 \mathrm{~kg} \mathrm{~N}^{-1}$ & 2.05 & 3.39 & 0.15 & 0.29 & 1.39 & 0.79 \\
\hline N3: $60 \mathrm{~kg} \mathrm{~N} \mathrm{ha}^{-1}$ & 2.09 & 3.61 & 0.18 & 0.34 & 1.49 & 0.87 \\
\hline N4: $90 \mathrm{~kg} \mathrm{~N} \mathrm{ha}^{-1}$ & 2.16 & 3.74 & 0.19 & 0.35 & 1.54 & 0.91 \\
\hline SEm \pm & 0.05 & 0.10 & 0.01 & 0.01 & 0.06 & 0.04 \\
\hline $\mathrm{CD}(\mathrm{P}=\mathbf{0 . 0 5})$ & 0.16 & 0.28 & 0.02 & 0.03 & 0.18 & 0.12 \\
\hline \multicolumn{7}{|c|}{ Population densities (D) } \\
\hline D1: $30 \times 10 \mathrm{~cm}$ & 2.17 & 3.69 & 0.18 & 0.34 & 1.54 & 0.87 \\
\hline D2: 25 x $10 \mathrm{~cm}$ & 2.05 & 3.57 & 0.17 & 0.32 & 1.40 & 0.84 \\
\hline D3: 20 x $10 \mathrm{~cm}$ & 1.96 & 3.35 & 0.15 & 0.30 & 1.35 & 0.82 \\
\hline D4: 15 x $10 \mathrm{~cm}$ & 1.86 & 3.21 & 0.14 & 0.28 & 1.32 & 0.73 \\
\hline SEm \pm & 0.05 & 0.10 & 0.01 & 0.01 & 0.06 & 0.04 \\
\hline $\mathrm{CD}(\mathrm{P}=\mathbf{0 . 0 5})$ & 0.16 & 0.28 & 0.02 & 0.03 & NS & NS \\
\hline \multicolumn{7}{|c|}{ Interaction (N x D) } \\
\hline SEm \pm & 0.11 & 0.20 & 0.01 & 0.02 & 0.12 & 0.08 \\
\hline $\mathrm{CD}(\mathrm{P}=\mathbf{0 . 0 5})$ & NS & NS & NS & NS & NS & NS \\
\hline CV $(\%)$ & 9.29 & 9.81 & 15.1 & 12.6 & 15.0 & 17.3 \\
\hline
\end{tabular}

Significantly superior number of actinomycetes $\mathrm{cfu} \mathrm{g}^{-1}$ was observed at $90 \mathrm{~kg}$ $\mathrm{N} \mathrm{ha}^{-1}$ as compared to other levels of nitrogen which can be attributed to higher root proliferation resulting in greater root mass, thereby increasing the release of organic substance from the root exudates and dead root cells. This is in line to the results reported by Oyewole et al., 2012 and Aliyu and Oyeyiola, 2012. Population of actinomycetes increased with increasing population density and greater population was obtained with $15 \times 10 \mathrm{~cm}$, however, it was on par with $20 \times 10 \mathrm{~cm}$ spacing. Lowest population was observed with wider spacing of $30 \times 10 \mathrm{~cm}$.

This might be due to secretion of phytochemicals and proteins from roots, which is an important way for plants to respond to and alter their environment, thus helping in enhancing production by favouring association with beneficial soil microbes. This was reported by Badri and Vivanco, 2009. Thus, it can be concluded that localized placement of ammoniacal nitrogen and phosphorous produced significant acidification in rhizosphere region, resulting in greater root proliferation and thereby, increasing content of macro and micro nutrients (viz., $\mathrm{N}, \mathrm{P}, \mathrm{K}, \mathrm{Zn}$ and $\mathrm{Fe}$ ) in the crop. Microbial count was found to be maximum with $90 \mathrm{~kg} \mathrm{~N}^{-1}$. Nutrient content per plant was higher with wider spacing of 30 x $10 \mathrm{~cm}$. Closer spacing of 15 x $10 \mathrm{~cm}$ was found to be optimum for higher microbial population. 
Table.2 $\mathrm{Zn}$ and Fe content (ppm) of groundnut as influenced by nitrogen levels and population densities

\begin{tabular}{|c|c|c|c|c|}
\hline \multirow{3}{*}{ Treatments } & \multicolumn{4}{|c|}{ Content (ppm) } \\
\hline & \multicolumn{2}{|c|}{ Zn } & \multicolumn{2}{|c|}{$\mathbf{F e}$} \\
\hline & Haulm & Seed & Haulm & Seed \\
\hline \multicolumn{5}{|l|}{ Nitrogen levels (N) } \\
\hline N1: 0 kg N ha $^{-1}$ & 32.8 & 10.8 & 152.1 & 49.8 \\
\hline N2: 30 kg N ha $^{-1}$ & 42.1 & 14.9 & 185.7 & 61.9 \\
\hline N3: 60 kg N ha ${ }^{-1}$ & 45.8 & 16.1 & 212.2 & 67.6 \\
\hline N4: 90 kg N ha ${ }^{-1}$ & 50.1 & 17.1 & 219.3 & 73.3 \\
\hline SEm \pm & 2.1 & 0.5 & 8.9 & 3.1 \\
\hline $\mathrm{CD}(\mathrm{P}=0.05)$ & 6.2 & 1.5 & 25.8 & 9.1 \\
\hline \multicolumn{5}{|c|}{ Population densities (D) } \\
\hline D1: $30 \times 10 \mathrm{~cm}$ & 46.7 & 15.7 & 208.7 & 68.2 \\
\hline D2: $25 \times 10 \mathrm{~cm}$ & 44.3 & 15.4 & 198.8 & 65.3 \\
\hline D3: $20 \times 10 \mathrm{~cm}$ & 41.7 & 14.5 & 188.8 & 63.4 \\
\hline D4: $15 \times 10 \mathrm{~cm}$ & 38.2 & 13.4 & 173.0 & 55.7 \\
\hline SEm \pm & 2.1 & 0.5 & 8.9 & 3.1 \\
\hline $\mathrm{CD}(\mathbf{P}=\mathbf{0 . 0 5})$ & 6.2 & 1.5 & NS & NS \\
\hline \multicolumn{5}{|c|}{ Interaction (N x D) } \\
\hline SEm \pm & 4.3 & 1.0 & 17.9 & 6.27 \\
\hline CD (P=0.05) & NS & NS & NS & NS \\
\hline CV $(\%)$ & 17.3 & 12.0 & 16.1 & 17.2 \\
\hline
\end{tabular}

Table.3 Total fungal, bacterial and actinomycetes count $\left(\times 10^{4}\right)$ per gram of soil as influenced by nitrogen levels and population densities $\left(\mathrm{CFU} \mathrm{g}^{-1}\right)$

\begin{tabular}{|c|c|c|c|}
\hline Treatments & $\begin{array}{l}\text { Fungal count } \\
\quad\left(\times 10^{4}\right)\end{array}$ & $\begin{array}{c}\text { Bacterial } \\
\text { count }\left(\times 1^{4}\right)\end{array}$ & $\begin{array}{l}\text { Actinomycetes } \\
\text { count }\left(\begin{array}{ll}x & 10\end{array}\right)\end{array}$ \\
\hline \multicolumn{4}{|l|}{ Nitrogen levels (N) } \\
\hline N1: 0 kg N ha ${ }^{-1}$ & 11.5 & 107.7 & 84.4 \\
\hline N2: $30 \mathrm{~kg} \mathrm{~N} \mathrm{ha}^{-1}$ & 15.6 & 151.0 & 119.6 \\
\hline N3: 60 kg N ha ${ }^{-1}$ & 18.2 & 210.4 & 175.5 \\
\hline N4: $90 \mathrm{~kg} \mathrm{~N} \mathrm{ha}^{-1}$ & 19.5 & 252.2 & 200.0 \\
\hline SEm \pm & 0.4 & 6.4 & 4.2 \\
\hline $\mathrm{CD}(\mathbf{P}=\mathbf{0 . 0 5})$ & 1.3 & 18.6 & 12.3 \\
\hline \multicolumn{4}{|l|}{ Population densities (D) } \\
\hline D1: $30 \times 10 \mathrm{~cm}$ & 14.0 & 147.2 & 119.1 \\
\hline D2: $25 \times 10 \mathrm{~cm}$ & 15.5 & 156.6 & 125.2 \\
\hline D3: $20 \times 10 \mathrm{~cm}$ & 17.2 & 207.4 & 163.3 \\
\hline D4: 15 x $10 \mathrm{~cm}$ & 18.2 & 210.1 & 171.8 \\
\hline SEm \pm & 0.4 & 6.4 & 4.2 \\
\hline CD (P=0.05) & 1.3 & 18.6 & 12.3 \\
\hline \multicolumn{4}{|l|}{ Interaction $(\mathbf{N} \times$ x $)$} \\
\hline SEm \pm & 0.9 & 12.9 & 8.5 \\
\hline $\mathrm{CD}(\mathbf{P}=\mathbf{0 . 0 5})$ & NS & NS & NS \\
\hline CV (\%) & 9.6 & 12.4 & 10.2 \\
\hline
\end{tabular}




\section{References}

Aliyu, M.B. and Oyeyiola, G.P. Rhizosphere bacterial flora of groundnut (Arachis hypogaea). Advances in Environment Biology. 2012; 5 (10): 3196-3202.

Badri, V.D and Vivanco, J.M. Regulation and function of root exudates. Plant, Cell and Environment. 2009; 32: 666-681.

Chavan, A.P., Jain, N.K and Mahadkar, U.V. Direct and residual effects of fertilizers and biofertlizers on yield, nutrient uptake and economy of groundnut (Arachis hypogaea)- rice (Oryza sativa) cropping system. Indian Journal of Agronomy. 2014; 59 (1): 53-58.

Das B.B, Dkhar M.S. Rhizosphere microbial populations and physico chemical properties as affected by organic and inorganic farming practices. AmericanEurasian Journal of Agricultural and Environmental Sciences. 2011; 10: 140150.

De-la-Pena, C., Lei, Z., Watson, B.S., Sumner, L.W and Vivanco, J.M. Rootmicrobe communication through protein secretion. Journal of Biological Chemistry. 2008; 283: 25247-25255.

El-Habbasha, S.F., Taha, M.H and Jafar, N.A. Effect of Nitrogen Fertilizer Levels and Zinc Foliar Application on Yield, YieldAttributes and Some Chemical Traits of Groundnut. Research Journal of Agriculture and Biological Sciences. 2013; 9 (1): 1-7.

Garcia, J.A.L., Barbas, C., Probanza, A., Barrientos, M.L and Manero F.J.G. Low molecular weight organic acids and fatty acids in root exudates of two Lupinus cultivars at flowering and fruiting stages. Phytochemical Analysis. 2001; 12: 305-311.

Jackson, M.L. Soil chemical analysis, Prentice Hall Indian Private Limited, New Delhi. 1973; 179-180.

Jing, J., Rui, Y., Zhang, F., Rengel, Z and Shen, J. Localized application of phosphorus and ammonium improves growth of maize seedlings by stimulating root proliferation and rhizosphere acidification. Field Crops Research. 2010; 119: 355-364.

Ma, Q., Tang, H., Rengel, Z and Shen, J. Banding phosphorus and ammonium enhances nutrient uptake by maize via modifying root spatial distribution. Crop and Pasture Science. 2013; 64 (10): 965-975.

Oyewole, O.A., Okoliegbe, I.N and Akwu, E.E. Comparative rhizosphere microbiological and physicochemical properties of Arachis Hypogeae (Groundnut) and HibiscusEsculentus (Okro). Natural products - An Indian Journal. 2012; 8 (9): 353-360.

Qinghua, M., Wang, X., Li, H., Li, H., Cheng, L., Zhang, F., Rengel, $\mathrm{Z}$ and Shen, J. Localized application of $\mathrm{NH}_{4}{ }^{+}-\mathrm{N}$ plus $\mathrm{P}$ enhances zinc and iron accumulation in maize via modifying root traits and rhizosphere processes. Field Crops Research. 2014; 164: 107-116

\section{How to cite this article:}

Mandakranta Chakraborty and Martin Luther. M. 2020. Rhizosphere Dynamics as Influenced by Nitrogen Levels and Plant Geometry in Groundnut (Arachis hypogeae L.). Int.J.Curr.Microbiol.App.Sci. 9(03): 2507-2513. doi: https://doi.org/10.20546/ijcmas.2020.903.287 